\title{
TransNIEMO: Economic Impact Analysis Using a Model of Consistent Interregional Economic and Network Equilibria
}

\author{
JoongKoo Cho / Peter Gordon \\ James E. Moore, II / Qisheng Pan \\ JiYoung Park / Harry W. Richardson
}

\author{
CESIFO WORKING PAPER NO. 4601 \\ CATEGORY 12: EMPIRICAL AND THEORETICAL METHODS \\ JANUARY 2014
}

An electronic version of the paper may be downloaded

- from the SSRN website:

- from the RePEc website:

- from the CESifo website:

www.SSRN.com

www.RePEc.org

www.CESifo-group.org/wp

\section{CESifo}




\title{
TransNIEMO: Economic Impact Analysis Using a Model of Consistent Interregional Economic and Network Equilibria
}

\begin{abstract}
We describe a model that integrates a multi-regional input-output model of the U.S. (50 states and the District of Columbia) with the national highway network. Interstate commodity shipments are placed on a congestible highway network. Simulations of major choke-point disruptions redirect traffic which increases the costs of some shipments. Increased costs show up in higher prices which help to determine a new input-output equilibrium. We find economic and network equilibria that are consistent. The simulations show only moderate economic impacts. We ascribe this to the resilience of highway network. The model provides state-level detail on who bears the costs of the disruptions.
\end{abstract}

JEL-Code: R110, R120, R130, R150, R400, R410, R490.

Keywords: multi-regional input-output model, highway network, interstate commodity shipments, highway infrastructure failure.

$$
\begin{gathered}
\text { JoongKoo Cho* } \\
\text { Epstein Department of Industrial and } \\
\text { Systems Engineering } \\
\text { University of Southern California } \\
\text { USA - Los Angeles, CA 90089 } \\
\text { joongkoc@usc.edu } \\
\text { James E. Moore, II } \\
\text { Epstein Department of Industrial and } \\
\text { Systems Engineering \& Sol Price School } \\
\text { of Public Policy } \\
\text { University of Southern California } \\
\text { USA - Los Angeles, CA 90089 } \\
\text { jmoore@usc.edu } \\
\text { JiYoung Park } \\
\text { Department of Urban and Regional } \\
\text { Planning / University at Buffalo } \\
\text { The State University of New York } \\
\text { USA - Buffalo, NY 14214 } \\
\text { jp292@buffalo.edu }
\end{gathered}
$$

Peter Gordon

Sol Price School of Public Policy University of Southern California

USA - Los Angeles, CA 90089

pgordon@usc.edu

Qisheng Pan

Department of Urban Planning and Environmental Policy

Texas Southern University

USA - Houston, TX 77004

pan_qs@tsu.edu

Harry W. Richardson

Sol Price School of Public Policy

University of Southern California

USA - Los Angeles, CA 90089

professorhwr@gmail.com 


\section{Introduction and Research Challenge}

Economic impact models that are spatially disaggregated are part of the legacy of regional science. Aggregation to the national level obscures important details and is potentially misleading whenever positive impacts in one place cancel negative impacts in another (the "wash" effect). Aggregated results are of limited interest to policymakers because of most politicians' keen and logical interest in impacts on their local constituencies.

Inter-regional and multi-regional input-output models were first developed largely at a theoretical level over a half-century ago to address these problems (e.g. Leontief (1936, 1941), Isard (1951), Miernyk (1965) and later Polenske (1980), Miller and Blair (1985)). In recent years, there have been important advances in the regionalization of national input-output data. Yet while the available multi-regional models measure trade between regions (Hewings et al., 2002), the infrastructure over which trade occurs on the national transportation networks remains neglected. In this paper, we present applications of TransNIEMO to address this omission. ${ }^{1}$ We add the nation's highway network to the National Interstate Economic Model (NIEMO), a multiregional input-output model that includes the 50 states and the District of Columbia as well as 47 industrial sectors, a model we had previously developed. ${ }^{2}$ TransNIEMO adds the nation's highway network which accommodates most of the intra- and inter-industry trade that NIEMO estimates. The new model seeks highway network and economic equilibria that are consistent with each other.

The U.S. economy is vulnerable to disruptions, including terrorist attacks and natural disasters. Modeling how disruptions at major choke points on the nation's highways might impact the U.S. economy on a state-by-state and industry-by-industry basis is of particular interest. We believe that TransNIEMO is the only operational model that can be used for this type of analysis. While this paper reports the results of hypothetical impacts on three major

\footnotetext{
${ }^{1}$ Several integrated models of freight transportation and economic effects have been developed for European countries. European examples include Tavasszy et al (1998)'s the Strategic Model for Integrated Logistics and Evaluations (SMILE) for the Netherlands, Cascetta et al.(2008) freight demand simulation model applied a multi regional input-out model for Italy, and Geerts and Jourguin (2001) developed a long-term planning model of freight transportation and multimodal networks for Belgium.

${ }^{2}$ On a smaller scale, we have used an initial version of TransNIEMO for a three-state area to estimate more local effects economic impact stemming from a hypothetical highway bridge disruption connecting California and Arizona (Park et al., 2011).
} 
choke points, disruptions from natural or man-made events on any other vulnerable highway link can easily be modeled by applying TransNIEMO.

In what follows, we cite the relevant literature (Section II), describe how a computable highway network and its constituent parts were assembled (Section III), explain the scenarios that were tested (Section IV), describe network flow results and economic consequences of various simulated disruptions (Section V), and wrap up with conclusions and reflections (Section VI).

\section{Integrating Highway Networks with Input-Output Models}

There are two standard models of the classic economic input-output (I-O) approach. The first, the Leontief demand-driven IO model, follows Leontief's early contributions $(1936,1941)$ with respect to how to generalize interdependencies between industries in an economy. The second, the Ghoshian supply-driven I-O model, was introduced by Ghosh in 1958 and suggested an alternative way to understand the interrelations between industries. Inter-industry linkages in the demand-driven I-O model account for technical relationships in the economy via production functions. In contrast, the supply-driven model is less transparent, suggesting fixed sales patterns, perhaps because of monopolistic markets or a centralized, planned market in which all resources are scarce except for one, and considers the best use of this non-scarce input in combination with scarce resources. This best use may be derived from a standard social welfare function (Ghosh, 1964). These are strong assumptions, but like fixed production coefficients in the Leontief model, may be plausible in the short run (Park, 2008; 2011; 2013).

Spatial extensions of the classic I-O model include interregional or multiregional I-O (IRIO or MRIO) models (Isard, 1951; Chenery, 1953; Moses, 1955); as well as empirical versions developed in the late 1970s (Polenske, 1980) and early 1980s (Jack Faucett Associates, 1983). Recently, Park et al. (2007) constructed a new demand-driven MRIO model, the National Interstate Economic Model (NIEMO), used in this paper. As demonstrated by Dietzenbacher (1997), the supply-driven I-O model can provide a more convenient formulation for estimating absolute cost increases than the Leontief price I-O model. We applied the supply-driven NIEMO in the cost estimations in this study. Our approach had been previously elaborated and empirically tested by Park (2008) and Park et al. (2008). 
Turning to models of highway networks, Hillestad et al. (2009) noted that an important element of an adaptable and resilient freight transportation system includes identification and analysis of key vulnerabilities in the freight system, and simulations of possible responses to the disruption. Also, Okuyama et al. (1999) and Kim et al. (2002) applied a Midwest regional economic model and missed capturing the full set of spillover effects. Unless a model accounts for secondary effects or substitutions in the economy at the national level, policy makers will not have the full picture.

This research was elaborated to extend the geographically limited version of TransNIEMO by Park et al. (2011) to address the regional freight transportation models discussed in Gordon and Pan (2001), Pan (2006), and Giuliano et al. (2007), to analyze

interregional and interstate freight flows, and to simulate the response of highway freight flows to disruptions in the national level. It uses data from the U.S. DOT's Freight Analysis Framework (FAF2) to establish a baseline of freight flows on the national highway network. It also creates highway bridge and tunnel disruption scenarios in specified regions to estimate statelevel costs of highway infrastructure failure, measured in terms of increased time and distance.

\section{Methods}

\section{III.1 Identifying Network Links and Centroids}

The first steps in the development of TransNIEMO involved the representation of a computable version of the nation's highway network. This task involved three challenges: to identify major economic and network centroids; to describe and connect the important highway links; and to include the tunnels and bridges that might be choke points if disrupted. Centroid identification was the most complex of these tasks, and is fully described in Park et al. (2009).

At the metropolitan scale, defining centroids to represent sources of aggregate demand in a relatively small traffic analysis zone and connecting this demand to physical facilities at the boundary of the zone is a relatively straightforward exercise. At the national level, the same step is more challenging. Analysis zones need to define a much larger region. An economic centroid characterizing this region aggregates a much larger volume of demand than in a metropolitan level model. 
Two definitions of centroid were used. The major metropolitan areas were designated as the economic centroids, while a representative sample of nearby highway nodal points were designated as network centroids. The economic centroids are defined to represent an economic center of gravity for the region, and as a result are most often near metropolitan areas that include considerable infrastructure. The transportation demand at each of the economic centroids is connected via virtual (dimensionless, costless) links to many network centroids in the vicinity of the economic centroid because it is unrealistic to load trucks onto the regional highway network connecting major metropolitan areas via a single network node at each location. We use econometric and spatial analysis to identify multiple network nodes at many highway interchanges via which to connect each regional economic centroid to the highway network. The total number of network centroids in our system is 1,877 . The total number of arcs in the original FAF network is 170,773 .

The Freight Analysis Framework (FAF2) highway provides link and node geographic reference data for the base network. The FAF origin-destination database employs 114 domestic regions defined in the 2002 Commodity Flow Survey (CFS) plus 17 international gateways and seven international regions. Because the goal of this study was to examine commodity or truck flows on the national highway network, we used the 114 domestic origin and destination regions in the FAF network to represent the economic centroids. There are 12,204 OD pairs representing total flows between economic centroids.

\section{III.2 Estimating the Impacts of Highway Infrastructure Failures}

The analytical framework for estimating the impacts of highway infrastructure failures on freight flows includes three steps: establishing the network baseline by loading freight flows onto the national highway system, designing scenarios for highway bridge failures and tunnel closures, and examining the changes of freight flows before and after the highway bridge or tunnel failures.

In the applications of our model, more than 275,000 highway network links were examined. The network link attributes also include capacity and speed. Link capacities were obtained from the FAF 2002 data set, which estimates capacities using the methodology in the 
Highway Capacity Manual (HCM) 2000. Free flow link speeds were estimated based on link classification. An equilibrium model is applied to estimate freight flows in the baseline and for the bridge collapse scenario. Freight tonnage was converted to passenger-car equivalent (PCE) values based on the ton-per-PCE ratios estimated by Giuliano et al. (2007).

\section{3 Economic Impacts of Disruptions: NIEMO and TransNIEMO}

TransNIEMO involves three sub-models, a national highway network model, a transportation cost impact model, and NIEMO (our demand-driven multi-regional input-output model). The various modeling steps are summarized in Figure 1. In that Figure, the various data sources (Data Inventory in upper-left large box) were described. The box on the left (Network Definition) was described in Section III.1; Network Disruption Scenarios (center box) were described in Section IV. Below that, Network Modeling was described in Section III.2. The upper right box (Transportation Cost Impact Model) and the box at the bottom of the Figure (Demand-Driven NIEMO) are described below this Section.

The tests described here are for a one-year disruption of selected highway links. NIEMO is linear, making it a simple matter to scale down the results to shorter periods. Three major research steps associated with the three sub-models are discussed in this section.

\section{III.3.1 Highway Network Model}

Freight analysis framework (FAF2) 2002 data were used to assemble and construct highway network links. The network was used to define bridge and tunnel collapse scenarios, and was also employed in the freight network model to estimate the changes in freight flows under various shut-down scenarios.

The highway network model is applied by combining the highway networks with the bridge or tunnel disruption scenarios. A user equilibrium (UE) model is applied twice for each test: first to develop a baseline and second by applying the scenario. The user equilibrium approach is appropriate when there is significant congestion on the network. As we are dealing with freight flows on highway networks among metropolitan regions, applying the UE algorithm 
is reasonable. A static user equilibrium framework is an approximation in this context, but it is computable and ensures that shortest paths are not overloaded because it respects the economic incentives faced by shippers. The results from applying the UE algorithm include the times and the distances from origin regions to destination regions. We assume that trip durations are related to truckers' labor costs and distance is associated with the other variable costs besides labor. The results from the network model simulations are used as inputs into the transportation cost impact model.

\section{III.3.2 Transportation Cost Impact Model (Supply-side Input-Output Model) and NIEMO (Demand-driven Multi-regional Input-Output Model)}

FAF provides a comprehensive data set but not all of the data are directly applicable to our research problem because services are also included in annual flows among NIEMO's industrial sectors. These service values must be excluded from the model. NIEMO freight flows are used as freight flow input values. However, NIEMO does not account for transportation shipment modes. Consequently truck proportions from FAF are used to apportion NIEMOestimated trade flows to obtain truck shipments. These are then loaded onto the highway network. 


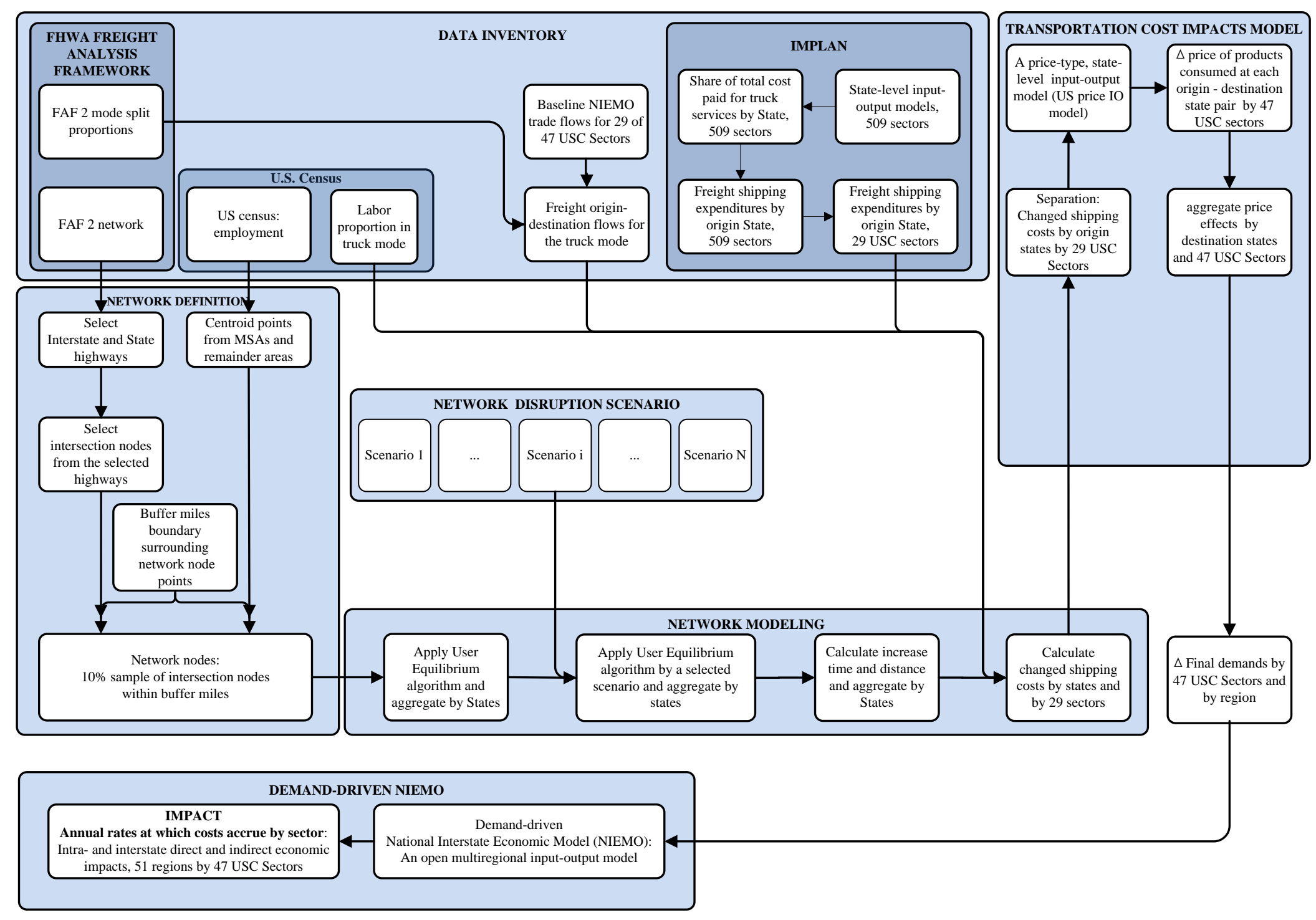

Figure 1. Framework of TransNIEMO 
Increases in shipping costs will increase commodity prices. This, in turn, suppresses consumer expenditures. Consequently, we also require data on the shipping costs associated with all the flows. Total shipping costs between states are estimated using data from NIEMO, IMPLAN, and FAF as follows,

$$
S C_{i j}^{k}=T T V_{i j}^{k} \times T P_{i j}^{k} \times T C V_{i}^{k}
$$

where

$S C_{i j}^{k}$ are aggregated shipping costs from state $\mathrm{i}$ to $\mathrm{j}$ by commodity sector $\mathrm{k}$.

$T T V_{i j}^{k}$ are total trade values obtained from NIEMO for 49 x 49 states (Hawaii is omitted).

$T P_{i j}^{k}$ are truck proportions of total trade calculated by applying truck output values divided by total output values obtained from FAF data. Data for 114 MSAs by 114 MSAs are aggregated to 49 states by 49 states.

$T C V_{i}^{k}=\frac{P T S_{i}^{k}}{T I V_{i}^{k}}$ are truck costs per value. These are the truck cost proportions in origin states obtained from IMPLAN. IMPLAN's sectors are aggregated to 29 Commodity Sectors (The "USC Sectors" that we developed are described in Table A4 of larger report at website noted below). PTS ${ }_{i}^{k}$ are the total value of purchased services by the trucking sector and $T I V_{i}^{k}$ are total output of industry sectors.

Increased travel time and distance proportions are estimated by applying the user equilibrium network model. Time changes and distance changes are separately modeled in equations (2) and (3).

$T_{i j}^{k}=S C_{i j}^{k} \times\left(P T C_{i j} \times P L C\right)$

where

$T_{i j}^{k}$ are increased costs caused by the increased time of travel. 
$P T C_{i j}$ are the proportions of time changes calculated as total increased time divided by total baseline time. Data for 114 MSA by 114 MSA flows are aggregated to 49 states by 49 states.

$P L C$ is the proportion of labor costs in operation of the transportation industry (0.65).

$D_{i j}^{k}=S C_{i j}^{k} \times\left(P D C_{i j} \times P V C\right)$

where

$D_{i j}^{k}$ are increased costs associated with increased shipping distance.

$P D C_{i j}$ are proportions of distance change calculated as total increased distance divided by total baseline distance. Data for 114 MSA by 114 MSA are aggregated to 49 states by 49 states.

PVC is the assumed proportion of variable costs in operation of the transportation industry (0.35).

Total increased shipping costs are estimated by adding the two increased costs, time and distance. See Equation (4).

$$
\Delta S C_{i j}^{k}=D_{i j}^{k}+T_{i j}^{k}
$$

where

$\Delta S C_{i j}^{k}$ are increased shipping costs from origin state i to destination state $\mathrm{j}$ for industry sector $\mathrm{k}$ resulting from an event. In the short run, shipping costs are assumed to be non-decreasing. In the event of an emergency, sellers can pass on higher costs in the short term. They may also cut prices because of competitive pressures, but only in the longer run.

As noted above, these increased shipping costs, $\Delta S C_{i j}^{k}$, are passed forward and lead to increased prices at destinations, resulting in lower consumer expenditures. This approach hinges on the idea that in the short run supply chains are more fixed than the household sector's expenditure budget. Households can be expected to hold much smaller inventories than 
intermediate industries and are, therefore, the most vulnerable to price hikes. The most vulnerable are the ones who are impacted.

The price increases can be calculated, and then the corresponding reductions in consumer expenditures treated as reduced final demand, subject to the standard restrictions on substitutions associated with the I-O perspective. We applied the supply-driven I-O model to develop more meaningful estimates of price increases which are suggested in absolute costs in the supply-side application. An application of a supply-driven I-O model is summarized in equation (5).

$$
\Delta P_{j}^{k}=\sum_{i=1}^{51}\left(\Delta S C_{i j}^{k} \times G_{j}\right)
$$

where

$\Delta P_{j}^{k}$ are decreased consumer expenditures at destination $\mathrm{j}$ and industry sector $k$.

$G_{j}=\left(I-B_{j}\right)^{-1}$ is a $47 \times 47$ supply-driven input-output inverse matrix where $B_{j}$ is the direct output-based technical coefficients matrix of destination state $j$.

$\Delta P_{j}^{k}$ can be aggregated either by states or by sector. $\sum_{k=1}^{47} \Delta P_{j}^{k}$ are direct impacts by states when $\Delta P_{j}^{k}$ are aggregated by sector and $\sum_{j=1}^{51} \Delta P_{j}^{k}$ are direct impacts by sector when $\Delta P_{j}^{k}$ are aggregated by state.

The reduced consumer expenditures associated with increased shipping costs drive reductions in household final demand. We assume that there are no substitution effects in the short term, and final demand is directly affected by the reduced consumer expenditures. Equation (6) applies the demand-driven NIEMO to estimate the state-by-state economic impacts resulting from these reductions in household final demand.

$$
\Delta X_{j}^{k}=\operatorname{DIVS} \times\left(-\Delta P_{j}^{k}\right)
$$

where 
$\Delta X_{j}^{k}$ are decreased final outputs in destination states $\mathrm{j}$ and industry sector $\mathrm{k}$. DIVS $=(\text { I-DNIEMO })^{-1}$, where DNIEMO denotes the $(47 \times 52)^{2}$ technical and trade coefficients in the demand-driven National Interstate Economic Model (NIEMO) $\Delta X_{j}^{k}$ can be aggregated either by states or by sector. $\sum_{k=1}^{47} \Delta X_{j}^{k}$ are total impacts by states when $\Delta X_{j}^{k}$ are aggregated by sector and $\sum_{j=1}^{51} \Delta X_{j}^{k}$ are total impacts by sector when $\Delta X_{j}^{k}$ are aggregated by state.

We applied the equation found in Berwick and Farooq (2003) to calculate truckers' labor cost per mile as

$L R P M+\frac{(T D / S+W T) * L R P H}{T D}$

where

$$
\begin{aligned}
& \text { LRPM = Labor (Wage) Rate Per Mile }=.493 \$ / \text { mile } \\
& \text { TD = Trip Distance }=100 \text { miles, } \\
& \text { S = Speed = } 65 \mathrm{MPH} \text {, } \\
& \text { WT = Wait Time = } 1 \text { hour, and } \\
& \text { LRPH = Labor (Wage) Rate Per Hour }=\$ 17 / \text { hour. }
\end{aligned}
$$

The equation given in the literature assumes $\mathrm{LRPH}=\$ 10 /$ hour and LRPM=0.29 $\$ / \mathrm{mile}$. We believe the current LRPH is close to $\$ 17$. As a result, we modified the numerical terms LRPM and LRPH in equation (8), and obtained $\$ 0.9$ per mile. In the literature, other variable costs are given as $\$ 0.48$ per mile, and we estimated labor cost to 65 percent of total variable cost, or

$$
0.65=0.9 /(0.9+0.48)
$$




\section{IV.Scenarios}

We selected interesting scenarios by identifying the nature and dimension of losses from possible disruptions along potentially major highway choke points. Two criteria were considered for selecting critical bridges or tunnels in the Interstate Highway Program. First, there should be high volumes of truck traffic on the bridge or tunnel. Second, there should be few alternatives available for detour in cases of emergency. For these reasons, we focused on the bridges over the Mississippi River and tunnels under mountain ranges.

According to the National Bridge Inventory (NBI) database, there were 599,766 bridges in the US in December 2007 (USDOT-FHWA 2008). Based on the information gathered from a variety of sources, including the American Association of State Highway and Transportation Officials (AASHTO), Historic Bridges of the U.S., and the Federal Highway Administration (FHWA) Freight Analysis Framework, there are about 28 bridges over the Mississippi River with Annual Average Daily Traffic (AADT) counts greater than 10,000.

Three scenarios were selected for this study. Tables 1 summarize relevant information for the selected bridges and the tunnel studied. The Memphis-Arkansas Memorial Bridge and Hernando de Soto Bridge accommodated 30,000 average daily truck trips in 2002 and these two bridges are relatively far away from alternative bridges. These two bridges were selected for the first scenario. Four other bridges over the Mississippi River, selected via the same criteria, were chosen for the second scenario. A tunnel disruption scenario involves the nation's longest tunnel, the Eisenhower Memorial Tunnel under the Rocky Mountain range; which, because of its location, also has very few alternates. 
Table 1. Bridges and Tunnel Selected for the Bridge/ Tunnel Disruption Scenario and Associated Truck Traffic

\begin{tabular}{|c|c|c|c|}
\hline Scenario & Bridge or Tunnel Name & $\begin{array}{l}\text { Highways } \\
\text { (Carries) }\end{array}$ & AADTT02 \\
\hline Scenario One & $\begin{array}{c}\text { Memphis-Arkansas Memorial Bridge } \\
\text { Hernando de Soto Bridge }\end{array}$ & $\begin{array}{l}\text { I-55 / US-61/US-64/US-70 } \\
\text { I-40 }\end{array}$ & $\begin{array}{l}19,021 \\
11,660\end{array}$ \\
\hline Scenario Two & $\begin{array}{c}\text { Horace Wilkinson Bridge } \\
\text { I-74 Bridge / Iowa-Illinois Memorial Bridge } \\
\text { Rock Island Centennial Bridge } \\
\text { I-280 Bridge }\end{array}$ & $\begin{array}{c}\text { I-10 } \\
\text { I-74 / US } 6 \\
\text { US } 67 \\
\text { I-280 }\end{array}$ & $\begin{array}{c}7,268 \\
5,260 \\
615 \\
2,240\end{array}$ \\
\hline Scenario Three & Eisenhower Memorial Tunnel & $\mathrm{I}-70$ & 3,571 \\
\hline
\end{tabular}

Notes: AADTT02 is the annual average daily truck traffic in FAF 2002 data.

\section{Scenario One: Two-bridge Closure Scenario}

The Mississippi River is divided into the upper Mississippi, from its source in Minnesota south to the Ohio River, and the lower Mississippi, from the Ohio to the Mississippi's mouth near New Orleans. In comparison to the Upper Mississippi River, the Lower Mississippi River is wider and has relatively fewer bridges. For example, there are only two bridges across the borders of Tennessee, Arkansas, and Mississippi: the Memphis-Arkansas Memorial Bridge and the Hernando de Soto Bridge as explained in Table 1. These accommodate some of the highest truck traffic flows across all the bridges over the Mississippi River.

The collapse of these two bridges would impose significant impacts on the level of service provided by the transportation networks due to limited alternatives in the immediate region for re-routing flows over the Mississippi River. Our first scenario assumes bridge failures for the Memphis-Arkansas Memorial Bridge and the Hernando de Soto Bridge. We seek to estimate all consequent re-routings of freight flows on the 275,168 links in the restricted national highway network. 


\section{Scenario Two: Four-bridge Closure Scenario}

In addition, we identified four bridges with the highest Annual Average Daily Truck Traffic (AADTT). These are the Horace Wilkinson Bridge on I-10 in Louisiana, the IowaIllinois Memorial Bridge on I-74, Rock Island Centennial Bridge on US 67, and the Interstate Highway I-280 Bridge. The I-74, US 67, and I-280 bridges are located at the border between Iowa and Illinois. Our second scenario assumes that these four bridges over the Mississippi River collapse at about the same time due to a terrorist attack.

\section{Scenario Three: Tunnel Closure Scenario}

Located west of Denver, Colorado, on Interstate highway 70, the Eisenhower Memorial Tunnel is a two-bore tunnel, 2.7 miles in length. It is one of the highway system's highest elevation tunnels and among the longest mountain tunnels built in the Interstate Highway Program. Table 1 shows the traffic of the Eisenhower Memorial Tunnel recorded in the FAF 2002 data set. Our third scenario assumes closure of this tunnel from either a terrorist attack or a natural disaster. 


\section{Model results \\ V.1 Network Effects}

Each economic centroid is connected to multiple network centroids in the vicinity of the economic centroid, and each network centroid serves as an origin for an equal share of the freight transportation requirements associated with the economic centroid. Each serves as a destination for an equal share of the demand imposed on the network at network centroids in the vicinity of other economic centroids. Once network equilibrium flows are achieved, travel times and changes in travel times between economic centroids are computed as averages across the pairs of network centroids corresponding to each pair of economic centroids. When network capacity is removed from the system, travel times on a few links decrease. These are links that are no longer accessible as a result of removing a link or links. However, alternative routes see an increase in flows and a decrease in level of service as freight flows divert away from routes that are no longer feasible.

Table 2 lists the top-20 OD pairs with the highest percentage of time difference between the baseline and four-bridge-collapse scenario, estimated from the equilibrium assignment model with capacity constraints. Based on the modeling results, the increased freight shipping time in the bridge collapse scenario was 674 million PCE*hours across all 12,204 OD pairs of economic centroids. The net increase in route travel times is 373,836 hours system-wide. Since economic centroids are associated with large, sub-state regions that are constrained by state boundaries, these results can be further aggregated to state-level results using standard GIS tools.

Similarly, Table 3 lists the top-20 OD pairs with the highest percentage of time difference between the baseline and two-bridge-collapse scenario, also calculated via the equilibrium assignment model with capacity constraints. The model estimated that freight shipping time increased 3,061 million PCE*hours across all 12,204 economic centroid OD pairs. The net increase in route travel times is considerably higher than in the case of the previous scenario, 1,573,773 hours system wide. As before, these results be aggregated to state-level values. Some numerical fidelity is lost because freight shipping times for state-to-state OD pairs are calculated from the times for corresponding economic centroids. 
Table 2. Top-20 OD Pairs with Highest \% Time Difference between Baseline and Four-Bridge Collapse Scenario Measured by User Equilibrium Assignment with Capacity Constraints

\begin{tabular}{|c|c|c|c|c|c|c|c|c|c|c|c|}
\hline \multirow[b]{2}{*}{ Origin } & \multirow[b]{2}{*}{ Destination } & \multirow[b]{2}{*}{ \#Path } & \multirow[b]{2}{*}{$\begin{array}{l}\text { OD val } \\
\text { (KPCE) }\end{array}$} & \multicolumn{2}{|c|}{ Original Network } & \multicolumn{2}{|c|}{ Impacted Network } & \multicolumn{2}{|c|}{ Difference } & \multicolumn{2}{|c|}{ \% Difference } \\
\hline & & & & $\begin{array}{c}\text { Avg } \\
\text { Time } \\
\text { (Hours) } \\
\end{array}$ & $\begin{array}{c}\text { Avg } \\
\text { Distance } \\
\text { (Miles) } \\
\end{array}$ & $\begin{array}{c}\text { Avg } \\
\text { Time } \\
\text { (Hours) } \\
\end{array}$ & $\begin{array}{c}\text { Avg } \\
\text { Distance } \\
\text { (Miles) } \\
\end{array}$ & $\begin{array}{c}\Delta \text { Time } \\
\text { (Hours) }\end{array}$ & $\begin{array}{l}\Delta \text { Distance } \\
\text { (Miles) }\end{array}$ & Time & Distance \\
\hline Washington & Washington & 25 & 2412.65 & 0.0774 & 2.5718 & 0.0832 & 2.5718 & 0.0058 & 0.0000 & $7.49 \%$ & $0.00 \%$ \\
\hline East St. Louis & Kansas City & 143 & 3741.14 & 9.3160 & 265.1774 & 9.9774 & 306.6700 & 0.6614 & 41.4926 & $7.10 \%$ & $15.65 \%$ \\
\hline East St. Louis & Kansas City & 117 & 2507.16 & 9.5857 & 283.3957 & 10.2616 & 310.0446 & 0.6759 & 26.6489 & $7.05 \%$ & $9.40 \%$ \\
\hline St. Louis & Kansas City & 99 & 4212.47 & 9.0395 & 268.3507 & 9.6479 & 288.2723 & 0.6084 & 19.9216 & $6.73 \%$ & $7.42 \%$ \\
\hline St. Louis & Kansas City & 121 & 5576.23 & 8.7973 & 253.8011 & 9.3875 & 281.3807 & 0.5902 & 27.5796 & $6.71 \%$ & $10.87 \%$ \\
\hline $\begin{array}{l}\text { Remainder of } \\
\text { New Jersey }\end{array}$ & $\begin{array}{l}\text { Virginia } \\
\text { Beach }\end{array}$ & 65 & 5175.00 & 9.7019 & 262.4011 & 10.2464 & 295.6473 & 0.5445 & 33.2462 & $5.61 \%$ & $12.67 \%$ \\
\hline Louisville & Cincinnati & 169 & 6029.04 & 4.0133 & 126.4906 & 4.2239 & 126.6708 & 0.2106 & 0.1802 & $5.25 \%$ & $0.14 \%$ \\
\hline Washington & Silver Spring & 65 & 3591.79 & 0.5582 & 20.8432 & 0.5848 & 21.2479 & 0.0266 & 0.4047 & $4.77 \%$ & $1.94 \%$ \\
\hline Washington & Richmond & 65 & 2197.48 & 4.4437 & 124.0159 & 4.6536 & 124.9630 & 0.2099 & 0.9471 & $4.72 \%$ & $0.76 \%$ \\
\hline Delaware & $\begin{array}{l}\text { Virginia } \\
\text { Beach }\end{array}$ & 169 & 5030.60 & 8.5889 & 257.2477 & 8.9713 & 277.8631 & 0.3824 & 20.6154 & $4.45 \%$ & $8.01 \%$ \\
\hline Louisville & Dayton & 143 & 4877.08 & 4.9912 & 171.2554 & 5.2044 & 172.5271 & 0.2132 & 1.2717 & $4.27 \%$ & $0.74 \%$ \\
\hline East St. Louis & $\begin{array}{c}\text { Remainder of } \\
\text { Missouri }\end{array}$ & 208 & 4791.78 & 6.4026 & 199.8073 & 6.6576 & 211.3535 & 0.2550 & 11.5462 & $3.98 \%$ & $5.78 \%$ \\
\hline East Chicago & Chicago & 231 & 7831.15 & 3.2123 & 72.2430 & 3.3392 & 73.6664 & 0.1269 & 1.4234 & $3.95 \%$ & $1.97 \%$ \\
\hline Baltimore & Columbus & 169 & 1679.37 & 15.5931 & 445.8562 & 16.2044 & 436.8825 & 0.6113 & -8.9737 & $3.92 \%$ & $-2.01 \%$ \\
\hline East St. Louis & Denver & 169 & 608.71 & 24.5111 & 870.7580 & 25.4584 & 904.0775 & 0.9473 & 33.3195 & $3.86 \%$ & $3.83 \%$ \\
\hline Louisville & Kansas City & 143 & 1425.34 & 17.4836 & 544.6757 & 18.1573 & 609.5848 & 0.6737 & 64.9091 & $3.85 \%$ & $11.92 \%$ \\
\hline Delaware & Richmond & 169 & 4857.46 & 8.0157 & 235.1792 & 8.3229 & 243.4783 & 0.3072 & 8.2991 & $3.83 \%$ & $3.53 \%$ \\
\hline Louisville & Kansas City & 117 & 776.48 & 17.7187 & 563.3867 & 18.3969 & 620.0807 & 0.6782 & 56.6940 & $3.83 \%$ & $10.06 \%$ \\
\hline St. Louis & Denver & 143 & 1358.99 & 23.9899 & 859.9821 & 24.8828 & 881.3679 & 0.8929 & 21.3858 & $3.72 \%$ & $2.49 \%$ \\
\hline $\begin{array}{c}\text { Remainder of } \\
\text { New Jersey }\end{array}$ & Raleigh & 65 & 381.47 & 13.4500 & 421.0213 & 13.9480 & 436.9897 & 0.4980 & 15.9684 & $3.70 \%$ & $3.79 \%$ \\
\hline
\end{tabular}


Table 3. Top-20 OD Pairs with Highest \%Time Difference in the Two Bridge Scenario in the FAF Network Measured by Authors' User Equilibrium Assignment with Capacity Constraints

\begin{tabular}{|c|c|c|c|c|c|c|c|c|c|c|c|}
\hline \multirow[b]{2}{*}{ Origin } & \multirow[b]{2}{*}{ Destination } & \multirow[b]{2}{*}{ \#Path } & \multirow[b]{2}{*}{$\begin{array}{l}\text { OD val } \\
(\mathrm{KPCE})\end{array}$} & \multicolumn{2}{|c|}{ Original Network } & \multicolumn{2}{|c|}{ Impacted Network } & \multicolumn{2}{|c|}{ Difference } & \multicolumn{2}{|c|}{ \% Difference } \\
\hline & & & & $\begin{array}{l}\text { Avg } \\
\text { Time } \\
\text { (Hours) }\end{array}$ & $\begin{array}{l}\text { Avg } \\
\text { Distance } \\
\text { (Miles) } \\
\end{array}$ & $\begin{array}{l}\text { Avg } \\
\text { Time } \\
\text { (Hours) }\end{array}$ & $\begin{array}{l}\text { Avg } \\
\text { Distance } \\
\text { (Miles) } \\
\end{array}$ & $\begin{array}{l}\Delta \text { Time } \\
\text { (Hours) }\end{array}$ & $\begin{array}{l}\Delta \text { Distance } \\
\text { (Miles) }\end{array}$ & Time & Distance \\
\hline Memphis & Arkansas & 216 & $4,942.52$ & 6.077 & 200.0925 & 8.8559 & 232.1458 & 2.7789 & 32.0533 & $45.73 \%$ & $16.02 \%$ \\
\hline Arkansas & Memphis & 216 & $2,898.35$ & 5.4773 & 197.1962 & 7.601 & 229.9408 & 2.1237 & 32.7446 & $38.77 \%$ & $16.61 \%$ \\
\hline Memphis & $\begin{array}{l}\text { Remainder of } \\
\text { Missouri }\end{array}$ & 144 & $3,380.14$ & 9.2256 & 337.2369 & 11.9935 & 364.4715 & 2.7679 & 27.2346 & $30.00 \%$ & $8.08 \%$ \\
\hline $\begin{array}{l}\text { Remainder of } \\
\text { Missouri }\end{array}$ & Memphis & 144 & $2,629.59$ & 8.76 & 339.8415 & 11.0556 & 378.9636 & 2.2956 & 39.1221 & $26.21 \%$ & $11.51 \%$ \\
\hline Memphis & St. Louis & 99 & $2,736.74$ & 6.7725 & 287.6912 & 8.4565 & 287.8123 & 1.684 & 0.1211 & $24.87 \%$ & $0.04 \%$ \\
\hline Memphis & Tulsa & 81 & 855.79 & 12.3741 & 447.5175 & 15.4327 & 491.103 & 3.0586 & 43.5855 & $24.72 \%$ & $9.74 \%$ \\
\hline Memphis & East St. Louis & 117 & $1,131.81$ & 7.1028 & 294.6997 & 8.6806 & 312.5435 & 1.5778 & 17.8438 & $22.21 \%$ & $6.05 \%$ \\
\hline Memphis & $\begin{array}{l}\text { Oklahoma } \\
\text { City }\end{array}$ & 81 & $1,144.63$ & 13.9647 & 492.7952 & 16.9553 & 549.5469 & 2.9906 & 56.7517 & $21.42 \%$ & $11.52 \%$ \\
\hline Tulsa & Memphis & 81 & 859.58 & 11.5858 & 440.5571 & 13.958 & 495.1701 & 2.3722 & 54.613 & $20.48 \%$ & $12.40 \%$ \\
\hline Memphis & Kansas City & 99 & 701.54 & 13.7844 & 507.1309 & 16.5921 & 548.2106 & 2.8077 & 41.0797 & $20.37 \%$ & $8.10 \%$ \\
\hline Mississippi & St. Louis & 264 & $1,215.35$ & 10.4096 & 486.1331 & 12.5198 & 496.123 & 2.1102 & 9.9899 & $20.27 \%$ & $2.05 \%$ \\
\hline Memphis & Kansas City & 81 & 790.95 & 13.8688 & 512.8989 & 16.6625 & 552.8285 & 2.7937 & 39.9296 & $20.14 \%$ & $7.79 \%$ \\
\hline Memphis & Lawton & 117 & 923.72 & 14.5516 & 539.5989 & 17.3091 & 579.7381 & 2.7575 & 40.1392 & $18.95 \%$ & $7.44 \%$ \\
\hline Memphis & $\begin{array}{l}\text { Remainder of } \\
\text { Kansas }\end{array}$ & 432 & 791.84 & 15.7737 & 597.221 & 18.7524 & 648.3663 & 2.9787 & 51.1453 & $18.88 \%$ & $8.56 \%$ \\
\hline Mississippi & East St. Louis & 312 & 622.94 & 10.7345 & 492.7173 & 12.6682 & 519.0557 & 1.9337 & 26.3384 & $18.01 \%$ & $5.35 \%$ \\
\hline Mississippi & Arkansas & 576 & $2,298.91$ & 7.173 & 267.8714 & 8.4606 & 275.7856 & 1.2876 & 7.9142 & $17.95 \%$ & $2.95 \%$ \\
\hline Kansas City & Memphis & 81 & 740.43 & 13.1589 & 527.6307 & 15.5112 & 548.2904 & 2.3523 & 20.6597 & $17.88 \%$ & $3.92 \%$ \\
\hline New Orleans & St. Louis & 121 & 348.62 & 13.35 & 665.6185 & 15.7326 & 676.0811 & 2.3826 & 10.4626 & $17.85 \%$ & $1.57 \%$ \\
\hline Kansas City & Memphis & 99 & 640.86 & 13.0884 & 520.1453 & 15.4227 & 538.6018 & 2.3343 & 18.4565 & $17.83 \%$ & $3.55 \%$ \\
\hline $\begin{array}{l}\text { Oklahoma } \\
\text { City }\end{array}$ & Memphis & 81 & 614.02 & 12.9968 & 485.3012 & 15.3035 & 542.0572 & 2.3067 & 56.756 & $17.75 \%$ & $11.70 \%$ \\
\hline
\end{tabular}


Table 4 reports the top-20 OD pairs with the highest percentage of time difference between the tunnel baseline and closure scenarios. Based on the model calculations, the total increase in freight shipping time in the tunnel closure scenario was 576 million PCE*hours for the flows between the economic centroid OD pairs. Total route travel time increases between centroid pairs was 293,252 hours. It is clear that the bridge collapse scenario is more costly than the tunnel closure scenario in terms of total shipping costs in PCE*hours. Further, the two-bridge-collapse scenario has significantly greater freight transportation impacts on the national highway network than did the alternative scenarios. This is undoubtedly the result of the limited number of alternative routes across the lower Mississippi, and the considerable diversion of flows produced from the loss of these links. The aggregate impact on route travel times is reduced as a result of the reduced freight transportation demands the loss of these bridges delivers to many links in the network.

\section{Table 4. Top-20 OD Pairs with Highest \%Time Difference in the Tunnel Scenario in the FAF Network}

\section{Measured by Authors’ User Equilibrium Assignment with Capacity Constraints}

\begin{tabular}{|c|c|c|c|c|c|c|c|c|c|c|c|}
\hline \multirow[b]{2}{*}{ \#Path } & \multirow[b]{2}{*}{ Destination } & \multirow[b]{2}{*}{ \#Path } & \multirow[b]{2}{*}{$\begin{array}{l}\text { OD Val } \\
(\mathrm{KCPE})\end{array}$} & \multicolumn{2}{|c|}{ Original Network } & \multicolumn{2}{|c|}{ Impacted Network } & \multicolumn{2}{|c|}{ Difference } & \multicolumn{2}{|c|}{ \% Difference } \\
\hline & & & & $\begin{array}{l}\text { Avg } \\
\text { Time } \\
\text { (Hours) }\end{array}$ & $\begin{array}{l}\text { Avg } \\
\text { Distance } \\
\text { (Miles) }\end{array}$ & $\begin{array}{l}\text { Avg } \\
\text { Time } \\
\text { (Hours) }\end{array}$ & $\begin{array}{l}\text { Avg } \\
\text { Distance } \\
\text { (Miles) }\end{array}$ & $\begin{array}{l}\Delta \text { Time } \\
\text { (Hours) }\end{array}$ & $\begin{array}{l}\Delta \text { Distance } \\
\text { (Miles) }\end{array}$ & Time & Distance \\
\hline Denver & $\begin{array}{l}\text { Colorado } \\
\text { Springs }\end{array}$ & 286 & $5,250.24$ & 4.4701 & 147.2388 & 4.8573 & 163.2640 & 0.3872 & 16.0252 & $8.66 \%$ & $10.88 \%$ \\
\hline $\begin{array}{l}\text { Colorado } \\
\text { Springs }\end{array}$ & Denver & 286 & $6,978.55$ & 3.9356 & 148.9149 & 4.2747 & 154.4561 & 0.3391 & 5.5412 & $8.62 \%$ & $3.72 \%$ \\
\hline $\begin{array}{l}\text { Virginia } \\
\text { Beach }\end{array}$ & Washington & 65 & $1,820.90$ & 5.2506 & 185.4439 & 5.6120 & 194.1242 & 0.3614 & 8.6803 & $6.88 \%$ & $4.68 \%$ \\
\hline $\begin{array}{l}\text { Remainder of } \\
\text { Arizona }\end{array}$ & Tucson & 48 & 547.62 & 8.1142 & 283.2915 & 8.6025 & 319.9456 & 0.4883 & 36.6541 & $6.02 \%$ & $12.94 \%$ \\
\hline Detroit & Cleveland & 247 & $3,250.51$ & 8.1479 & 212.1253 & 8.6044 & 201.3256 & 0.4565 & -10.7997 & $5.60 \%$ & $-5.09 \%$ \\
\hline
\end{tabular}




\begin{tabular}{|c|c|c|c|c|c|c|c|c|c|c|c|}
\hline $\begin{array}{l}\text { Colorado } \\
\text { Springs } \\
\end{array}$ & $\begin{array}{l}\text { Colorado } \\
\text { Springs }\end{array}$ & 484 & $18,991.65$ & 5.6769 & 195.7112 & 5.9879 & 200.9215 & 0.3110 & 5.2103 & $5.48 \%$ & $2.66 \%$ \\
\hline Richmond & Washington & 65 & $1,966.75$ & 4.4716 & 124.8251 & 4.7018 & 122.7343 & 0.2302 & -2.0908 & $5.15 \%$ & $-1.67 \%$ \\
\hline $\begin{array}{l}\text { Virginia } \\
\text { Beach }\end{array}$ & Arlington & 169 & 3,910.82 & 5.1743 & 186.3768 & 5.4103 & 191.9705 & 0.2360 & 5.5937 & $4.56 \%$ & $3.00 \%$ \\
\hline Washington & Washington & 25 & $1,169.30$ & 0.0774 & 2.5718 & 0.0809 & 2.5718 & 0.0035 & 0.0000 & $4.52 \%$ & $0.00 \%$ \\
\hline Phoenix & Denver & 65 & 203.89 & 23.3198 & 894.1576 & 24.3305 & 898.9331 & 1.0107 & 4.7755 & $4.33 \%$ & $0.53 \%$ \\
\hline Detroit & Pittsburgh & 221 & $2,536.94$ & 11.4584 & 327.9988 & 11.9395 & 329.6250 & 0.4811 & 1.6262 & $4.20 \%$ & $0.50 \%$ \\
\hline St. Louis & $\begin{array}{l}\text { Indianapolis } \\
\text { city (balance) }\end{array}$ & 121 & 1,936.33 & 7.9232 & 266.7490 & 8.2536 & 294.8386 & 0.3304 & 28.0896 & $4.17 \%$ & $10.53 \%$ \\
\hline Louisville & Cincinnati & 169 & $2,387.55$ & 4.0133 & 126.4906 & 4.1779 & 135.1950 & 0.1646 & 8.7044 & $4.10 \%$ & $6.88 \%$ \\
\hline East St. Louis & $\begin{array}{l}\text { Indianapolis } \\
\text { city (balance) }\end{array}$ & 143 & 1,364.92 & 7.2922 & 239.3810 & 7.5903 & 263.7704 & 0.2981 & 24.3894 & $4.09 \%$ & $10.19 \%$ \\
\hline Delaware & Camden & 143 & $2,285.84$ & 1.3459 & 53.4612 & 1.4006 & 53.3452 & 0.0547 & -0.1160 & $4.06 \%$ & $-0.22 \%$ \\
\hline New Mexico & Denver & 286 & $1,510.40$ & 10.0302 & 432.7385 & 10.4286 & 451.6375 & 0.3984 & 18.8990 & $3.97 \%$ & $4.37 \%$ \\
\hline $\begin{array}{l}\text { Oklahoma } \\
\text { City }\end{array}$ & New Mexico & 198 & 799.78 & 19.2989 & 632.3813 & 20.0600 & 659.2125 & 0.7611 & 26.8312 & $3.94 \%$ & $4.24 \%$ \\
\hline Grand Rapids & Cleveland & 171 & $2,194.21$ & 10.6561 & 342.0840 & 11.0668 & 328.3309 & 0.4107 & -13.7531 & $3.85 \%$ & $-4.02 \%$ \\
\hline $\begin{array}{l}\text { Remainder of } \\
\text { Michigan }\end{array}$ & Cleveland & 399 & 2,981.19 & 10.2120 & 307.2122 & 10.6012 & 298.3683 & 0.3892 & -8.8439 & $3.81 \%$ & $-2.88 \%$ \\
\hline Minneapolis & Wyoming & 208 & 648.18 & 19.9055 & 777.6148 & 20.6623 & 803.8577 & 0.7568 & 26.2429 & $3.80 \%$ & $3.37 \%$ \\
\hline
\end{tabular}




\section{VI.1 Economic Consequences}

We find that, as a proportion of the nation's total output, the losses experienced in all three scenarios are relatively small. We ascribe this result to the high levels of resilience (mainly redundancies) of the highway network. However, our results show that there are significant differences in state-by-state as well as industry-by-industry impacts

Tables 5A, 6A, and 7A show the estimated economic losses aggregated for States; Tables 5B, 6B, and 7B show the economic losses aggregated for sectors. Only the most impacted states and sectors are shown here; more detailed results are shown in a more detailed report which also includes more maps of highway approaches near the impacted areas are available at http://create.usc.edu/TRANSNIEMO_Dec\%2031_2010_Project\%20Report.pdf

As shown in Table 5A, Missouri (MO), Ohio (OH), and California (CA) are the three most impacted States in the two-bridge disruption scenario. Missouri and Ohio are near the Mississippi River and California's ports handle most of the nation's trans-Pacific trade. In terms of sectors, USC Sectors 1 (live animals, live fish, meat, seafood, etc.), 5 (other prepared foodstuffs, fats, oils), 31 (construction), and 32 (wholesale trade) are most heavily impacted by this event, as shown in Table 5B. Impacts for the case of the four-bridge disruption scenario are shown in Tables 6A and 6B. Missouri (MO), Colorado (CO), and New York (NY) are the top three impacted states. The same four USC Sectors experience the most severe impacts. Tables 7A and 7B show the results for the tunnel disruption simulation. Colorado (CO), Ohio (OH), and California (CA) and the same four USC sectors are again the most impacted.

Interestingly, several states distant from the target bridges are seriously impacted. Possible reasons for these results could be explained by the network algorithm that we applied. The UE algorithm considers traffic congestion; when there is congestion in any region, truck flows are diverted to other routes. So even though the state is not proximate to the closed bridges, that state can be affected. Second, freight volumes in the state may explain the phenomenon. For example, California is severely affected in all three scenarios although it is not near the various target bridges or the tunnel. California's two major ports of Los Angeles and Long Beach handle about 60 percent of container imports to the U.S. Large portions of these 
imported cargos are delivered by truck to the rest of the U.S. Third, network connections may be another factor explaining the results. If major highways are connected to the disrupted bridges and, and if a state uses that highway for significant freight movements, then that state can also be affected by the closure.

The unexpected result is that the total output losses are relatively small in both absolute and relative terms, despite the obvious importance of the facilities identified in these scenarios. There is apparently sufficient redundancy in the U.S. highway network that re-routings can be found that impose relatively small costs on truckers and on the economy as a whole. 
Table 5A. Top 5 State Economic Losses: Two-Bridge Closure Scenario (\$ Millions, 2001)

\begin{tabular}{|c|c|c|c|c|c|c|}
\hline State & $\begin{array}{l}\text { Direct } \\
\text { Impact }\end{array}$ & $\begin{array}{l}\text { Indirect } \\
\text { Impact }\end{array}$ & $\begin{array}{c}\text { Total } \\
\text { Impact }\end{array}$ & $\begin{array}{c}\text { \% of U.S. } \\
\text { Total }\end{array}$ & $\begin{array}{l}\text { \% change in } \\
\text { Total Output }\end{array}$ & $\begin{array}{c}\text { Total } \\
\text { Output }\end{array}$ \\
\hline $\mathrm{OH}$ & 16.9 & 14.4 & 31.2 & $9.87 \%$ & $0.0045 \%$ & 696,020 \\
\hline MO & 12.9 & 9.6 & 22.5 & $7.10 \%$ & $0.0067 \%$ & 336,920 \\
\hline CA & 10.4 & 10.9 & 21.3 & $6.74 \%$ & $0.0009 \%$ & $2,254,933$ \\
\hline $\mathrm{TX}$ & 8.1 & 10.7 & 18.8 & $5.94 \%$ & $0.0013 \%$ & $1,434,570$ \\
\hline IL & 8.8 & 8.9 & 17.7 & $5.59 \%$ & $0.0021 \%$ & 851,737 \\
\hline US Total & 155.3 & 161.3 & 316.6 & $100 \%$ & $0.0018 \%$ & $\begin{array}{r}17,769,75 \\
7\end{array}$ \\
\hline $\begin{array}{l}\text { Rest of } \\
\text { World }\end{array}$ & 0.0 & 14.5 & 14.5 & & & \\
\hline Total & 155.3 & 175.8 & 331.2 & & & \\
\hline
\end{tabular}

Table 5B. Top 5 Sector Economic Losses: Two-Bridge Closure Scenario, by Sector (\$ Millions, 2001)

\begin{tabular}{|c|c|c|c|c|c|c|}
\hline $\begin{array}{l}\text { Industry } \\
\text { Sector }\end{array}$ & $\begin{array}{c}\text { Direct } \\
\text { Impact }\end{array}$ & $\begin{array}{l}\text { Indirect } \\
\text { Impact }\end{array}$ & $\begin{array}{c}\text { Total } \\
\text { Impact }\end{array}$ & $\begin{array}{c}\text { \% of U.S. } \\
\text { Total } \\
\end{array}$ & $\begin{array}{l}\text { \% change in } \\
\text { Total Output }\end{array}$ & $\begin{array}{c}\text { Total } \\
\text { Output }\end{array}$ \\
\hline USC31 & 18.8 & 1.1 & 19.9 & $6.29 \%$ & $0.0020 \%$ & $1,013,113$ \\
\hline USC25 & 14.3 & 4.7 & 19.0 & $6.00 \%$ & $0.0042 \%$ & 447,184 \\
\hline USC32 & 2.4 & 14.5 & 16.9 & $5.33 \%$ & $0.0019 \%$ & 875,258 \\
\hline USC47 & 6.6 & 8.8 & 15.4 & $4.86 \%$ & $0.0020 \%$ & 755,883 \\
\hline USC5 & 9.3 & 5.0 & 14.3 & $4.50 \%$ & $0.0050 \%$ & 286,070 \\
\hline US Total & 155.3 & 161.3 & 316.6 & $100 \%$ & $0.0018 \%$ & $17,769,757$ \\
\hline $\begin{array}{l}\text { Rest of } \\
\text { World }\end{array}$ & 0.0 & 14.5 & 14.5 & & & \\
\hline Total & 155.3 & 175.8 & 331.2 & & & \\
\hline
\end{tabular}

Table 6A. Top 5 State Economic Losses: Four-Bridge Closure Scenario (\$ Millions, 2001)

\begin{tabular}{|c|c|c|c|c|c|c|}
\hline State & $\begin{array}{c}\text { Direct } \\
\text { Impact } \\
\end{array}$ & $\begin{array}{l}\text { Indirect } \\
\text { Impact } \\
\end{array}$ & $\begin{array}{c}\text { Total } \\
\text { Impact } \\
\end{array}$ & $\begin{array}{c}\text { \% of U.S. } \\
\text { Total } \\
\end{array}$ & $\begin{array}{l}\text { \% change in } \\
\text { Total Output }\end{array}$ & $\begin{array}{c}\text { Total } \\
\text { Output } \\
\end{array}$ \\
\hline $\mathrm{MO}$ & 9.2 & 6.5 & 15.7 & $11.20 \%$ & $0.0047 \%$ & 336,920 \\
\hline CA & 4.1 & 4.8 & 8.9 & $6.35 \%$ & $0.0004 \%$ & $2,254,933$ \\
\hline $\mathrm{OH}$ & 4.2 & 4.3 & 8.5 & $6.05 \%$ & $0.0012 \%$ & 696,020 \\
\hline IN & 4.4 & 4.0 & 8.4 & $5.97 \%$ & $0.0022 \%$ & 377,496 \\
\hline $\mathrm{TX}$ & 3.3 & 4.6 & 7.9 & $5.60 \%$ & $0.0005 \%$ & $1,434,570$ \\
\hline US Total & 68.9 & 71.5 & 140.4 & $100 \%$ & $0.0008 \%$ & $17,769,757$ \\
\hline $\begin{array}{l}\text { Rest of } \\
\text { World }\end{array}$ & 0.0 & 6.4 & 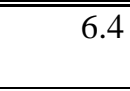 & & & \\
\hline Total & 68.9 & 77.9 & 146.8 & & & \\
\hline
\end{tabular}


Table 6B. Top 5 Sector Economic Losses: Four-Bridge Closure Scenario by Sector (\$ Millions, 2001)

\begin{tabular}{|c|c|c|c|c|c|c|}
\hline $\begin{array}{l}\text { Industry } \\
\text { Sector }\end{array}$ & $\begin{array}{l}\text { Direct } \\
\text { Impact }\end{array}$ & $\begin{array}{c}\text { Indirect } \\
\text { Impact }\end{array}$ & $\begin{array}{c}\text { Total } \\
\text { Impact }\end{array}$ & $\begin{array}{c}\text { \% of U.S. } \\
\text { Total } \\
\end{array}$ & $\begin{array}{l}\text { \% change in } \\
\text { Total Output }\end{array}$ & $\begin{array}{c}\text { Total } \\
\text { Output }\end{array}$ \\
\hline USC31 & 8.8 & 0.5 & 9.3 & $6.61 \%$ & $0.0009 \%$ & $1,013,113$ \\
\hline USC25 & 6.2 & 2.0 & 8.2 & $5.84 \%$ & $0.0018 \%$ & 447,184 \\
\hline USC32 & 1.0 & 6.4 & 7.4 & $5.29 \%$ & $0.0008 \%$ & 875,258 \\
\hline USC5 & 4.6 & 2.5 & 7.0 & $5.01 \%$ & $0.0025 \%$ & 286,070 \\
\hline USC47 & 2.9 & 3.9 & 6.8 & $4.81 \%$ & $0.0009 \%$ & 755,883 \\
\hline US Total & 68.9 & 71.5 & 140.4 & $100 \%$ & $0.0008 \%$ & $\begin{array}{r}17,769,75 \\
7\end{array}$ \\
\hline $\begin{array}{l}\text { Rest of } \\
\text { World }\end{array}$ & 0.0 & 6.4 & 6.4 & & & \\
\hline Total & 68.9 & 77.9 & 146.8 & & & \\
\hline
\end{tabular}

Table 7A. Top 5 State Economic Losses: Tunnel Closure Scenario (\$ Millions, 2001)

\begin{tabular}{|c|c|c|c|c|c|c|}
\hline State & $\begin{array}{c}\text { Direct } \\
\text { Impact } \\
\end{array}$ & $\begin{array}{c}\text { Indirect } \\
\text { Impact } \\
\end{array}$ & $\begin{array}{c}\text { Total } \\
\text { Impact }\end{array}$ & $\begin{array}{c}\% \text { of U.S. } \\
\text { Total } \\
\end{array}$ & $\begin{array}{l}\text { \% change in } \\
\text { Total Output }\end{array}$ & $\begin{array}{c}\text { Total } \\
\text { Output }\end{array}$ \\
\hline $\mathrm{CO}$ & 10.7 & 31.7 & 42.4 & $21.91 \%$ & $0.0128 \%$ & 330,456 \\
\hline $\mathrm{OH}$ & 10.6 & 5.2 & 15.8 & $8.14 \%$ & $0.0023 \%$ & 696,020 \\
\hline CA & 5.8 & 9.4 & 15.2 & $7.83 \%$ & $0.0007 \%$ & $2,254,933$ \\
\hline IN & 5.8 & 4.8 & 10.5 & $5.44 \%$ & $0.0028 \%$ & 377,496 \\
\hline NY & 4.8 & 5.3 & 10.0 & $5.19 \%$ & $0.0008 \%$ & $1,300,766$ \\
\hline US Total & 73.7 & 119.8 & 193.5 & $100 \%$ & $0.0011 \%$ & $\begin{array}{r}17,769,75 \\
7 \\
\end{array}$ \\
\hline $\begin{array}{l}\text { Rest of } \\
\text { World }\end{array}$ & 0.0 & 8.3 & 8.3 & & & \\
\hline Total & 73.7 & 128.1 & 201.8 & & & \\
\hline
\end{tabular}

Table 7B. Top 5 Sector Economic Losses: Tunnel Closure Scenario by Sector (\$ Millions, 2001)

\begin{tabular}{|c|c|c|c|c|c|c|}
\hline $\begin{array}{l}\text { Industry } \\
\text { sector }\end{array}$ & $\begin{array}{l}\text { Direct } \\
\text { Impact }\end{array}$ & $\begin{array}{c}\text { Indirect } \\
\text { Impact }\end{array}$ & $\begin{array}{l}\text { Total } \\
\text { Impact }\end{array}$ & $\begin{array}{c}\text { \% of U.S. } \\
\text { Total }\end{array}$ & $\begin{array}{l}\text { \% change in } \\
\text { Total Output }\end{array}$ & $\begin{array}{c}\text { Total } \\
\text { Output }\end{array}$ \\
\hline USC31 & 10.4 & 6.7 & 17.1 & $4.24 \%$ & $0.0017 \%$ & $1,013,113$ \\
\hline USC32 & 1.1 & 8.6 & 9.7 & $2.42 \%$ & $0.0011 \%$ & 875,258 \\
\hline USC1 & 3.5 & 5.6 & 9.2 & $2.27 \%$ & $0.0053 \%$ & 173,097 \\
\hline USC5 & 4.6 & 4.4 & 9.0 & $2.23 \%$ & $0.0032 \%$ & 286,070 \\
\hline USC47 & 3.3 & 5.1 & 8.4 & $2.08 \%$ & $0.0011 \%$ & 755,883 \\
\hline US Total & 73.7 & 119.8 & 193.5 & $100 \%$ & $0.0023 \%$ & $17,769,757$ \\
\hline Rest of World & 0.0 & 8.3 & 8.3 & & & \\
\hline Total & 73.7 & 128.1 & 201.8 & & & \\
\hline
\end{tabular}




\section{Conclusions}

This study describes a methodology for estimating the sector-by-sector and state-by-state economic impacts of hypothetical highway bridge collapse and tunnel closure scenarios. A regional freight transportation model developed in our previous studies has been extended to endogenize and analyze interregional and interstate freight flows. It is an equilibrium model with capacity constraints. The Frank-Wolfe algorithm (Frank and Wolfe, 1956) was incorporated into the model to compute user equilibrium flows on the national highway network.

Infrastructure planning in light of the terrorist threat as well as the possibility of natural disasters and degradation from wear and tear begins with an assessment of the economic value of alternative investments. One way to assess economic value is to estimate the economic losses that would result were any element of the infrastructure degraded. A modeling approach to this problem involves very extensive disaggregation. All states and many economic sectors are engaged in continuous trade at very substantial levels. Most of this trade takes place via trucks on the national highway system (including Interstate highways and major roads). Representing all of this complexity in an operational model was our primary task. In this paper we have described the steps involved in assembling the data and testing the model. We have also described three major tests of TransNIEMO to illustrate its capabilities.

One scenario hypothesized the collapse of four highway bridges in Louisiana and at the border of Iowa and Illinois. The second scenario assumed the collapse of two bridges with the highest traffic volume over the Lower Mississippi River in the Memphis area. The third scenario hypothesized the closure of the Eisenhower Memory Tunnel at Denver, Colorado. The network and economic effects of bridge collapse and tunnel closure on were examined. The simulation results showed that bridge collapse scenario is worse than the tunnel closure scenario in terms of total shipping costs in PCE*hours of travel measured at either the regional or state level. The collapse of two bridges in the Memphis area triggers the greatest increase in freight shipping costs. The results from the equilibrium model clearly show the widespread ripple effects of the bridge collapse and tunnel closure on the national highway network while the popular all-ornothing assignment model would limit the effects to the directly impacted highways.

From a policy perspective, one unexpected result is the small adjustments needed even when high-traffic-volume bridges and tunnels are destroyed. Re-routing involves very modest 
increases in freight costs. In the very short run, for trucks already en route, the additional time and distance costs could be substantial. However, once the disruptions are known, the extensive redundancy in the national highway and major roads system permits long-distance trucking companies to choose alternative routes that add little, if anything, to freight costs. Therefore route redundancy is important and maintaining state is clearly beneficial.

There are some limitations in our approach, especially in the capacity constraints on freight movement. The representation of congestion cost follows a metropolitan-level perspective that relies on an assumption of steady-state flows. This is only a first order approximation for flows in a national network. Still, there is empirical evidence of freight sensitivity to congestion costs (Winston and Langer 2006), and the user equilibrium model provides much more realistic results relative to an all-or-nothing assignment approach, especially for freight re-routing on the highways closer to the collapsed bridges. Unfortunately, passenger flows have not yet been incorporated into the equilibrium model with capacity constraints because the passenger flow data are unavailable for the FAF2002-based highway network. Consequently, the results do not reflect any interactions between passenger flows and freight flows on the national highway network.

This study only considered the re-routing of freight flows on a single mode, i.e. highway network. It did not incorporate other modes, especially the rail network. In ongoing research, the rail network will be combined with the highway network to build up an integrated freight transportation network and a multi-modal freight model is being developed to estimate the change of freight flows in the bridge collapse and tunnel closure scenarios. However, we suspect that short-run mode substitution options are very limited.

ACKNOWLEDGEMENT: The authors would like to thank these individuals for their skilled assistance: SooHyun Cho, Eunha (Eileen) Jun, Christine Nguyen, SungHo Ryu, SungSu (Stephen) Yoon 


\section{References}

Berwick, M. and M. Farooq, 2003, Truck Costing Model for Transportation Managers, Upper Great Plains Transportation Institute, North Dakota State University.

Cascetta, E., Marzano, V., Papola, A., 2008, Multi-regional Input-Output Models for Freight Demand Simulation at a National Level, in Ben-Akiva, M, Meersman, H., Voorde, E.V.D., Recent Developments in Transport Modelling: Lessons for the Freight Sector, Emerald Group Publishing.

Chenery, H.B., 1953, Regional Analysis, in The Structure and Growth of the Italian Economy, edited by H.B. Chenery, P.G. Clark and V.C. Pinna, U.S. Mutual Security Agency, Rome: 98-139.

Dietzenbacher, E. 1997. In Vindication of the Ghosh Model: A Reinterpretation as a Price Model. Journal of Regional Science 37, no. 4: 629-651. doi:10.1111/0022-4146.00073.

Frank, Marguerite and Philip Wolfe. 1956. An algorithm for quadratic programming. Naval Research Logistics Quarterly 3, no.1-2: 95-110.

Geerts, J. F. and G. Jourguin, 2001, "Freight transportation planning on the European multimodal network: the case of the Walloon region,” European Journal of Transport and Infrastructure Research, 1: 91-106.

Giuliano, Genevieve Gordon, Peter, Qisheng Pan, JiYoung Park, and LanLan Wang. 2007. Estimating freight flows for metropolitan area highway networks using secondary data sources. Networks and Spatial Economics 10, no. 1: 73-91. doi: 10.1007/s11067-0079024-9.

Gordon, Peter and Qisheng Pan. 2001. Assembling and Processing Freight Shipment Data: Developing a GIS-Based Origin-Destination Matrix for Southern California Freight Flows. Sacramento, CA: California Department of Transportation. Report No. FHWA/CA/OR-2001-15.

Ghosh, A., 1958, Input-Output Approach in an Allocation System, Economica, 25 (97): 58-64.

Ghosh, A., 1964, Experiments with Input-Output Models: An Application to the Economy of the

United Kingdom, 1948-55, London, Cambridge University Press.

Hewings, Geoffrey, Michael Sonis, David E. Boyce, 2002, Trade, networks, and hierarchies: modeling regional and interregional economies, Springer-Verlag, Heidelberg, Germany

Hillestad, Richard, Ben D. Van Roo, and Keenan D. Yoho. 2009. Key Issues in Modernizing the U.S. Freight-Transportation System for Future Economic Growth. Santa Monica, CA: Rand Corporation. ISBN/EAN: 9780833047489.

Isard, Walter. 1951. Interregional and Regional Input-Output Analysis: A Model of a Space Economy. The Review of Economics and Statistics 33: 318-328.

Jack Faucett Associates, INC, 1983, The Multiregional Input-Output Accounts, 1977: Introduction and Summary, Vol. I (Final Report), prepared for the US Department of Health and Human Services, Washington.

Kim, T.J., H. Ham, and D.E. Boyce (2002). "Economic impacts of transportation network changes: Implementation of a combined transportation network and input-output model.” Regional Science, 81(2): 223-246.

Leontief, W., 1936, Quantitative Input and Output Relations in the Economic System of the United States, Review of Economic Statistics, XVIII (3): 105-125.

Leontief, W., 1941, The Structure of American Economy, 1919-1929: An Empirical of Equilibrium Analysis, Cambridge, MA, Harvard University Press.

Miernyk, William H., 1965, The elements of input-output analysis, New York: Random House. 
Miller, Ronald E. and Peter D., 1985, Blair, Input-Output Analysis: Foundations and Extensions, Prentice Hall.

Moses, L.N., 1955, The Stability of Interregional Trading Patterns and Input-Output Analysis, American Economic Review, 45: 803-832.

Okuyama, Y., G. J.D. Hewings, T.J. Kim, D.E. Boyce, H. Ham, and J. Sohn (1999). “Economic Impacts of an Earthquake in the New Madrid Seismic Zone: A Multiregional Analysis,” in William M. Elliott and Peter McDonough eds. Optimizing Post-Earthquake Lifeline System Reliability, Technical Council on Lifeline Earthquake Engineering, Monograph No.16: 592601.

Pan, Qisheng. 2006. Freight Data Assembling and Modeling: Methodologies and Practice. Journal of Transportation Planning and Technology 29, no. 1: 43-74.

Park, J Y, P Gordon, J E Moore II, H W Richardson, S Kim, and Y Kim§, 2008, "Estimating the State-by-State Economic Impacts of Hurricane Katrina,” p147-186, in HW Richardson, P Gordon and JE Moore II, eds, Natural Disaster Analysis after Hurricane Katrina Cheltenham: Edward Elgar.

Park, JiYoung, Joongkoo Cho, and SungSu Yoon, 2009, "Determining Regional Network Boundaries (RNBs) for Sub-state Regions from US Highway Network Nodes Data," presented at 2009 National Urban Freight Conference (NUFC), Hotel Maya, Long Beach, CA, October 21-23.

Park, JY, 2008, “The Economic Impacts of Dirty- Bomb Attacks on the Los Angeles and Long Beach Ports: Applying the Supply-driven NIEMO (National Interstate Economic Model)," Journal of Homeland Security and Emergency Management, 5 (1), Article 21.

Park, JY, 2013, “Application of a Price-Sensitive Supply-Side Input-Output Model to an Examination of the Economic Impacts of Hurricane Katrina and Rita Disruptions of the US Oil-Industry,” Ecological Economics (forthcoming)

Park, JY, J Cho, Gordon, P, J E Moore II, H W Richardson, S Yoon, 2011, Adding a Freight Network to a National Interstate Input-Output Model: a TransNIEMO Application for California, Journal of Transport Geography 19 (6): 1410-1422.

Park, J.Y. (2011). “The Supply-Driven Input-Output Model: A Reinterpretation and Extension.” presented at the 19th International Input-Output Association conference, Alexandria, VA.

Park, J.Y., P. Gordon, J. E. Moore II, and H. W. Richardson, L. Wang, 2007, "Simulating The State-by-State Effects of Terrorist Attacks on Three Major US Ports: Applying NIEMO (National Interstate Economic Model),” in HW Richardson, P Gordon and JE Moore II, eds, The Economic Costs and Consequences of Terrorism

Polenske, K.R., 1980, The U.S. Multiregional Input-Output Accounts and Model, DC Health, Lexington, MA.

Tavasszy, L. A., van de Vlist, M., Ruijgrok, C. and van de Rest, J. (1998) Scenario-wise analysis of transport and logistic systems with a SMILE. Paper presented at the 8th WCTR Conference, Antwerp.

U.S. Department of Transportation- Federal Highway Administration (USDOT-FHWA). 2008. Our Nation's Highways 2008. Washington D. C. FHWA-PL-08-021.

Winston, Clifford and Ashley Langer. 2006. The effect of government highway spending on road user's congestion costs, Journal of Urban Economics 60: 463-483. 